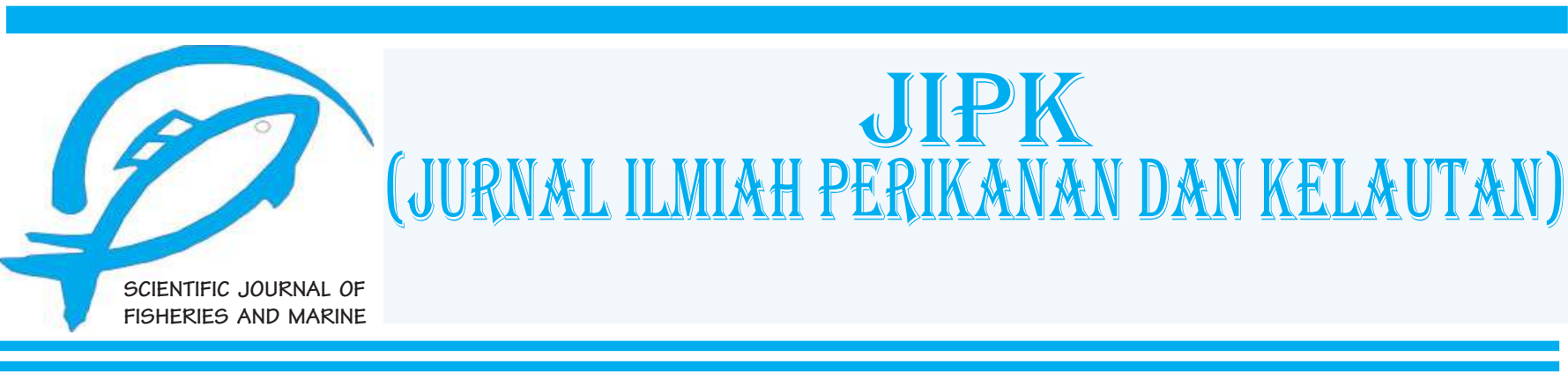

Research Article

\title{
Fish Feed Formulation with the Addition of Sludge of Dairy Wastewater and Fermented Wheat Bran
}

\section{Widya Pangestika1 ${ }^{1}$, Sugili Putra ${ }^{2}$}

${ }^{1}$ Department of Fisheries Product Processing, Politeknik Kelautan dan Perikanan Pangandaran, Pangandaran, Indonesia ${ }^{2}$ Department of Nuclear Technochemistry, Sekolah Tinggi Teknologi Nuklir, Babarsari Street, Yogyakarta, Indonesia

\section{OPEN $\bigcirc$ ACCESS \\ ARTICLE INFO \\ Received: Desember 25, 2019 \\ Accepted: January 22, 2020 \\ Published: February 27, 2020 \\ *) Corresponding author: \\ E-mail:widya.pangestika@kkp.go.id}

\section{Keywords:}

Aspergillus niger

buoyancy

ferric chloride

growth rate

stability

This is an open access article under the CC BY-NC-ND license (http://creativecommons.org/licenses/by-nc-nd/4.0/)

\begin{abstract}
Dairy wastewater contains suspended solids, which are very difficult to settle naturally. This waste could be treated by using ferric chloride, due to its ability to bind suspended solids and to form brown solid of Iron (III) hydroxide. The optimal amount of $\mathrm{FeCl} 3$ in coagulating dairy wastewater was $0.15 \mathrm{~g}$ of $\mathrm{FeCl} 3$ for every $250 \mathrm{~mL}$ of wastewater. This sludge could be utilized into something useful for the organism, such as: fish. The sludge of dairy wastewater could be mixed with other ingredients to make fish feed. In this research; we made two variations of fish feeds (feed B and feed C). Wheat bran, one of the ingredients used to make fish feed, was fermented using Aspergillus niger to increase the crude protein content and to lower crude fiber content. The addition of fermented wheat bran in fish feed formulation could increase the crude protein content in feed B (which had $0.085 \%$ iron) by $5.78 \%$ and feed C (which had $1.703 \%$ iron) by $5.17 \%$. By using simultaneous linear equations, fish feed formulation was conducted by adding sludge of dairy wastewater, fermented wheat bran, rebon flour, starch, and vitamin $\mathrm{C}$. The results indicated that feed $\mathrm{B}$ and feed $\mathrm{C}$ had better stability and buoyancy than feed A, as the commercial feed. Feed $\mathrm{C}$ also had the highest crude protein of all feeds, amounting to $32.057 \%$. Feed $\mathrm{C}$ also gave the best result in increasing Nile tilapia's growth rate. The result showed that sludge of dairy wastewater and fermented wheat bran could be added to fish feed formulation.
\end{abstract}

Cite this as: Pangestika, W., \& Putra, S. (2020). Fish Feed Formulation with the Addition of Sludge of Dairy Wastewater and Fermented Wheat Bran. Jurnal Ilmiah Perikanan dan Kelautan, 12(1):21-30. http://doi.org/10.20473/jipk.v12i1.18110 


\section{Introduction}

Most farmers in aquaculture had invested 60\%$70 \%$ on the feed (Coloso, 2015). This cost could be reduced by using more efficient ingredients for the diet costs less and are more sustainable. Some examples of the other ingredients are insect meals (Arru et al., 2019), and plant sources (Bhosale et al., 2010). In this study, another ingredient that would be added as an additive in fish feed is a sludge of dairy wastewater. Not only for making fish feed, but we also applied the zero waste strategy by utilizing the wastewater.

Suspended Solids (SS) of dairy wastewater contains the organic particles. The more suspended solids in dairy wastewater, the more sludge would be obtained as the final result of waste treatment. Nowadays, sludge of dairy wastewater was often used as fertilizer for plants. If the sludge are not reutilized, it would accumulated and pollute, the environment.

Generally, the waste contains pollutants that are present as colloids. Colloids are stable in the wastewater because they have electric charges. To eliminate the colloids, they must be destabilized to form larger and heavier floc, which would be removed by coagulation, flocculation, and deposition (Koohestanian et al., 2008).

Ferric chloride acts as a coagulant, which dissociates into ions when added into wastewater. This dissociation reaction could be called as a hydrolysis reaction (Rand, 2003). Ion Fe3 + has a tendency to polarize water and to encourage hydrolysis. This type of hydrolysis is usually occurred in $\mathrm{Al3}+$ and $\mathrm{Fe} 3+$ (Essington, 2004).

Initially, species would form hydrated molecules (such as: Fe (H2O)63+). The hydroxo metal complex ions which is produced would be positively charged, then the solution would be acidic due to hyrogen cations. These complex ions would form a gradual mechanism to produce neutral $\mathrm{Fe}(\mathrm{OH}) 3$, which is brown solid. The mechanism of $\mathrm{Fe}(\mathrm{OH}) 3$ formation could be seen in Eq. (1), (2), and (3) (Rand, 2003).

$$
\begin{aligned}
& \mathrm{Fe}\left(\mathrm{H}_{2} \mathrm{O}\right)_{6}{ }^{3+} \leftrightarrow \leftrightarrow \mathrm{Fe}\left(\mathrm{H}_{2} \mathrm{O}\right)_{5} \mathrm{OH}^{2+}+\mathrm{H}^{+} \\
& \mathrm{Fe}\left(\mathrm{H}_{2} \mathrm{O}\right)_{5} \mathrm{OH}^{2+} \leftrightarrow \leftrightarrow \mathrm{Fe}\left(\mathrm{H}_{2} \mathrm{O}\right)_{4}(\mathrm{OH})_{2}^{+}+\mathrm{H}^{+} \\
& \mathrm{Fe}\left(\mathrm{H}_{2} \mathrm{O}\right)_{4}(\mathrm{OH})_{2}^{+} \leftrightarrow \leftrightarrow \mathrm{Fe}\left(\mathrm{H}_{2} \mathrm{O}\right)_{3}(\mathrm{OH})_{3}{ }^{\circ}+\mathrm{H}^{+}
\end{aligned}
$$

The overall reaction is illustrated in Equation (4). $\mathrm{Fe}\left(\mathrm{H}_{2} \mathrm{O}\right)_{6}{ }^{3+} \leftrightarrow \leftrightarrow \mathrm{Fe}\left(\mathrm{OH}_{2}\right)_{3}(\mathrm{OH})_{3}{ }^{\circ}+3 \mathrm{H}^{+}$

Nazullawaty (2013) had studied the addition of fermented sludge of dairy wastewater to fish feed which result in the increase of protein content in tilapia after being fed by the feed. From the studies, it was known that the addition of fermented sludge of dairy wastewater could raise the protein content of tilapia to $18.51 \%$. Hassan et al. (2008) also had the same opinion that fermentation of wheat bran could increase the protein as much as $1.33 \%$. Aspergillus niger produced cellulose complex enzymes and several important components which were needed to break bonds of cellulose in crude fiber to produce glucose (Yusak, 2004). Given crude fiber in excessive amounts could cause interference of the absorption process in the small intestine (Afrianto and Liviawaty, 2005).

Not only the coagulation and fermentation processes, but proper formulation of fish feed is also needed. A optimsl formulation would cause good buoyancy and the stability of the feed in the water. High quality of fish feed needs to be achieved to reduce feed wastage and loss of nutrients due to the expansion in the water (Felix and Oscar, 2018). Tilapia is a floating feeder, so the feed needs to be stable and float in water. Yang et al. (2018) had studies that floating feed could be made by adding buoyant materials that could reduce the density of fish feces and cause feeding efficient.

The sludge that had been produced by coagulation-flocculation processes was iron-richest due to its coagulant, ferric chloride. High protein and high iron levels was added to the diet to increase the quality. This research's main focus is to formulate a good fish feed by utilizing sludge of dairy wastewater and fermented wheat bran.

\section{Materials and Methods}

This study was conducted in February 2015 until July 2015 in Chemical Process Laboratory, Sekolah Tinggi Teknologi Nuklir, Indonesia. The flow chart of the process, including the process of coagulationflocculation, fermentation, fish feed formulation, and fish feed trial (Figure 1).

\subsection{Dairy wastewater coagulation-flocculation}

$250 \mathrm{~mL}$ of dairy wastewater was put into $1 \mathrm{~L}$ beaker glass while the temperature was set at room temperature. Ferric chloride $5 \%$ was added as much as $5 \mathrm{~mL}, 7 \mathrm{~mL}, 9$ $\mathrm{mL}, 11 \mathrm{~mL}, 13 \mathrm{~mL}$, and $15 \mathrm{~mL}$ into six beaker glasses, which contained waste. Then, the glasses were stirred quickly for 1 minute. The stirring speed was lowered and left constant for 15 minutes. The solution was allowed to settle for 30 minutes (Sarparastzadeh et al.,2007). The process for dairy wastewater coagulation-flocculation is presented in Figure 1. The procedure was repeated for $\mathrm{FeCl}_{3}$ at concentrations of $2 \%$ and $3 \%$. 


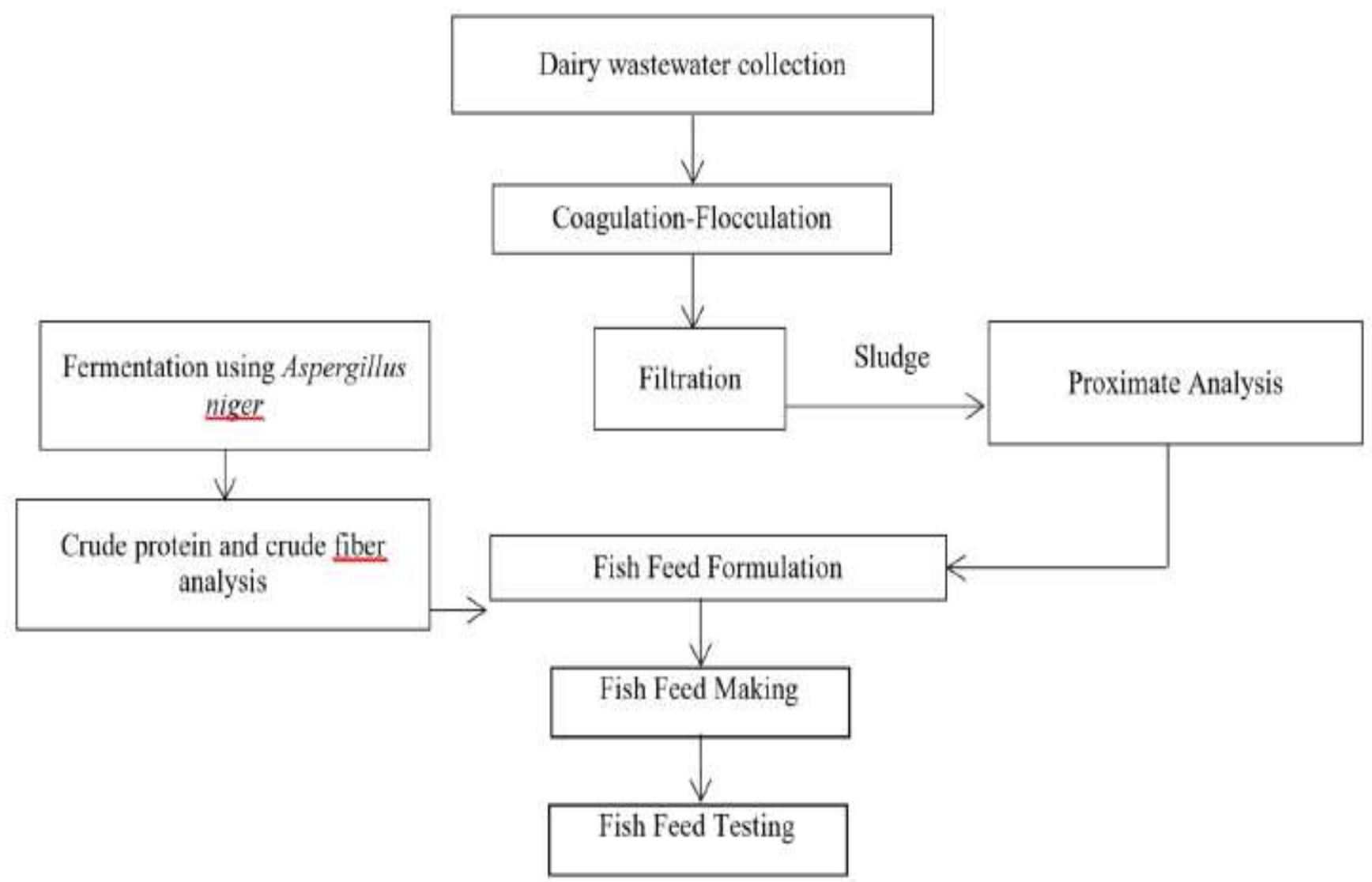

Figure 1. Process of making fish feed by utilizing dairy wastewater and fermentation process

\subsection{Wheat bran fermentation}

Wheat bran was mixed with urea about $5 \%$ of the amount of feed. Warm water was added into it until the dough could be grasped. The dough was kept at room temperature. Aspergillus niger, was added with the ratio up to $8 \mathrm{~g} / \mathrm{kg}$ of dried feed.. After 3-days of fermentation the dough was dried in the oven (Memmert UN55 Universal Oven, Germany) at $60^{\circ} \mathrm{C}$ (Mirwandhono et al., 2006).

\subsection{Fish feed formulation}

The crude protein and iron level of each ingredient must be known to make a good fish feed formulation. There were two types of feed that were made in this study, namely: feed B (containing $0.085 \%$ iron) and feed $\mathrm{C}$ (containing $1.703 \%$ iron), while feed A (commercial feed) was used as a comparative feed. Fish feed formulation was made by using simultaneous linear equations. The content of each ingredient is tabulated below.

Table 1

Eq. (5), (6), and (7) for feed B according to

$31.93 \mathrm{D}+18.55 \mathrm{E}+62.44 \mathrm{~F}=31.93$

$$
\begin{aligned}
& 17.03 \mathrm{D}+0.0145 \mathrm{E}+0.014 \mathrm{~F}=0.085 \\
& 51.04 \mathrm{D}+81.44 \mathrm{E}+37.55 \mathrm{~F}=62.985
\end{aligned}
$$
feed C

We were using Eq. (8), (9), and (10) for making

$$
\begin{aligned}
& 31.93 \mathrm{G}+18.55 \mathrm{H}+62.44 \mathrm{I}=31.93 \\
& 7.03 \mathrm{G}+0.0145 \mathrm{H}+0.014 \mathrm{I}=1.703 \\
& 51.04 \mathrm{G}+81.44 \mathrm{H}+37.55 \mathrm{I}=61.367
\end{aligned}
$$

D, E, F was the percentage of sludge of dairy wastewater, the percentage of fermented wheat bran, and the percentage of rebon flour, respectively that was added to make feed B, G, H, I was the percentage of sludge of dairy wastewater, the percentage of fermented wheat bran, and the percentage of rebon flour respectively that was added to make feed $\mathrm{C}$.

\subsection{The process of feed-making}

Two types of fish feed were made in this research. Feed B contains of $0.085 \%$ iron, and Feed C contains $1.703 \%$ iron. These feeds were analyzed, and compared to commercial feed, as Feed A. 
Sludge of dairy wastewater, rebon flour, starch, and fermented wheat bran were mixed in accordance to feed formulation in Table 2. Cassava's piths were cut into small size by using laboratory blender (ISOLAB, Germany Cat No. 602.21.001). Vitamin C and cassava pith were added to the mixture. After formed into pellets, the feed was dried in an oven at $60^{\circ} \mathrm{C}$. The pellets were removed from the oven after the water content of the pellets was less than $13 \%$.

\subsection{Physical test of formulated feed}

Pellet diameters were measured by using a vernier caliper. Stability of feeds was also measured by putting $5 \mathrm{~g}$ of feed into a beaker filled with water. The changes that occurred were observed until the whole pellets were dissolved. The buoyancy of the feeds was also determined by measuring the time required for each pellet to sink.

\subsection{Chemical test of formulated feed}

Proximate analysis of fish feed was performed based on SNI 01-2891-1992. Analysis of iron content was also carried out by using atomic absorption spectrophotometers (AAS 2-Solaar Series Thermo Scientific, USA) using the standard addition method.

\subsection{Fish feeding trial}

Nile tilapia was used as the experimental object. Three cages of Nile tilapia were used, containing 17 tilapia in every pond. Nile tilapia in pond 1 was fed by commercial feed while Nile tilapia in pond 2 and pond 3 were fed by feed B and feed C respectively. Feed A and $\mathrm{B}$ were given four times a day while feed $\mathrm{C}$ was given once in two days as a supplementary diet. Nile tilapia in pond 3 was fed by a combination of commercial feed and feed $\mathrm{C}$ while not being fed with feed $\mathrm{C}$, Nile tilapia were fed by feed A. Feeding trial was carried out in 4 weeks. We checked the weight of the Nile tilapia was checked every week (Pangestika and Putra, 2019) and the growth rate (GR) of Nile tilapia was calculated as seen in Equation 11 (Uliza et al., 2017).

$$
G R=\frac{W_{t}-W_{0}}{t}
$$

Where $\mathrm{W}_{\mathrm{t}}$ is the final average weight of tilapia $(\mathrm{g}), \mathrm{W}_{\mathrm{o}}$ is the initial average weight of tilapia $(\mathrm{g})$, and $\mathrm{t}$ is the feeding trial time (d).

Table 1. The analysis of crude protein and an iron level of raw materials in fish feeds

\begin{tabular}{lcccc}
\hline \multirow{2}{*}{ Ingredients } & \multicolumn{2}{c}{ Feed B } & \multicolumn{2}{c}{ Feed C } \\
\cline { 2 - 5 } & Crude Protein (\%) & Iron Level (\%) & Crude Protein (\%) & Iron Level (\%) \\
\hline Sludge & 31.93 & 17.03 & 31.93 & 17.03 \\
Fermented Wheat & 18.55 & 0.015 & 18.55 & 0.015 \\
Bran & 62.44 & 0.014 & 62.44 & 0.014 \\
Rebon Flour & 31.93 & 0.085 & 31.93 & 1.703 \\
\hline Fish Feed & &
\end{tabular}

Description: Feed B was contained $0.085 \%$ of iron; Feed C containing $1.703 \%$ of iron.

Table 2. The composition of raw materials in fish feeds

\begin{tabular}{lcc}
\hline \multirow{2}{*}{ Ingredients } & \multicolumn{2}{c}{ Proportion (\%) } \\
\cline { 2 - 3 } Sludge & In Feed B & In Feed C \\
Fermented Wheat Bran & 0.42 & 9.93 \\
Rebon Flour & 62.11 & 55.5 \\
Starch & 32.47 & 29.57 \\
Vitamin C & 5 & 5 \\
Cassava's pith & 0.4 & 0.4 \\
\hline
\end{tabular}

Description: Feed B was containing $0.085 \%$ of iron; Feed C containing $1.703 \%$ of iron. 


\section{Results and Discussion}

\subsection{Determination of the optimal concentration of $\mathrm{FeCl}_{3}$}

The effect of adding $\mathrm{FeCl}_{3}$ to dairy wastewater could be seen in Figure 2. The lowest Suspended Solids (SS) levels was obtained by adding $0.15 \mathrm{~g}$ of $\mathrm{FeCl}_{3}$. Flocks formed by adding $0.15 \mathrm{~g}$ of $\mathrm{FeCl}_{3}$ were greater than other mass variations. Once the $\mathrm{FeCl}_{3}$ was put into the solution, the complex ions that were positively charged, as Eq. (1)-(3). They would bind the hydroxide ions then formed brownish solid that settled at the bottom, as Figure 3 illustrated. The process made the solution above the sludge became clear and reduced SS in wastewater drastically.

The less $\mathrm{FeCl}_{3}$, which was added, the smaller flocks would be formed due to the inability of $\mathrm{Fe}(\mathrm{OH})_{3}$ to trap colloidal particles. The ability of metal hydroxide solids to trap colloidal particles was directly proportional to the amount of floc formed (Wulan et al., 2010). To the contrary, adding more $\mathrm{FeCl}_{3}$ increased $\mathrm{SS}$ content in the wastewater. This was indicated by the solution that was getting more yellow. It appeared because the equilibrium in Equation (3) was shifting to the left, causing the complex of $\mathrm{Fe}(\mathrm{OH})^{2+}$ to be dissolved (Weiner, 2000). Excessive addition of $\mathrm{FeCl}_{3}$ could decrease $\mathrm{pH}$ and raised the amount of hydrogen cation.

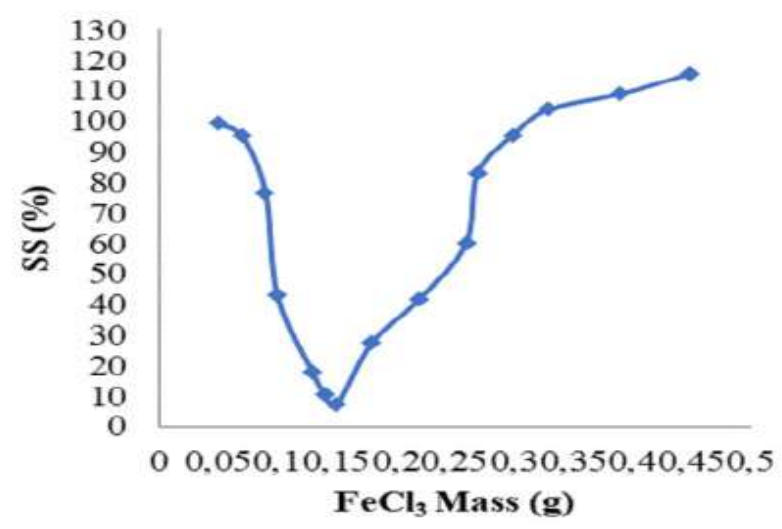

Figure 2. The effect of $\mathrm{FeCl}_{3}$ mass to $\mathrm{SS}$ percentage in dairy wastewater

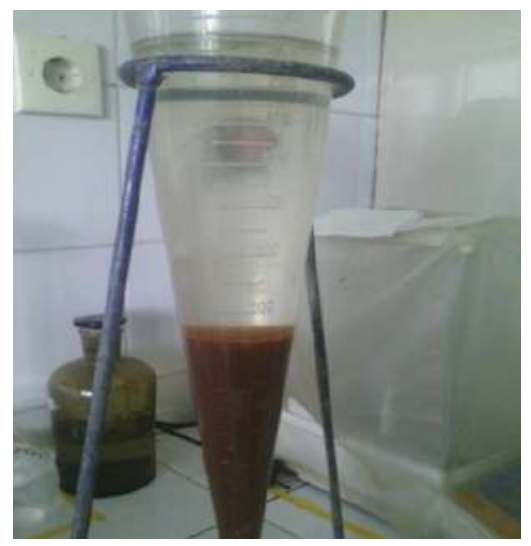

Figure 3. Brownish solid occurred at the sedimentation process

\subsection{Wheat bran fermentation}

Fermentation of wheat bran was carried out to increase the amount of of crude protein than other ingredients of fish feed. It would increased crude protein and decreased crude fiber, as could be seen in Table 3 and Figure 4.

Table 3. The comparison of water content, crude protein, and crude fiber among fermented and unfermented wheat bran

\begin{tabular}{cccc}
\hline $\begin{array}{l}\text { Types of } \\
\text { Wheat Bran }\end{array}$ & $\begin{array}{c}\text { Water } \\
\text { Content } \\
\text { (\%) }\end{array}$ & $\begin{array}{c}\text { Crude } \\
\text { Protein } \\
(\mathbf{\%})\end{array}$ & $\begin{array}{c}\text { Crude } \\
\text { Fiber (\%) }\end{array}$ \\
\hline Unfermented & 10.20 & 16.655 & 7.81 \\
Fermented & 14.62 & 23.779 & 7.45 \\
\hline
\end{tabular}

Crude protein level was decreasing after 3-days of fermentation while the crude fiber in wheat bran was increasing after the period (Figure 4). However, the highest rise of crude protein occurred on the third day of fermentation due to the increasing of mycelium of molds on the substrate. Cell biomass contained 40-65\% protein, in other words, we could say that $A$. niger was a source of single-cell protein (PST) (Supriatna, 2005). The more molds that grew, the higher crude protein content would be obtained because some mold cells are proteins. The secretion of extracellular enzymes by $A$. niger also played a role in increasing crude protein content (Indariyanti and Rakhmawati, 2013). In addition, the increased protein appeared because $A$. niger synthesized the urease enzyme to convert urea to ammonia and carbon dioxide. Then, ammonia was used to form amino acids (Nazullawaty, 2013; Mirwandhono et al., 2006). Urea, which was added before fermentation, would produce fixed nitrogen, and it would be counted as crude protein.

However, after three days of fermentation, the protein content in the substrate decreased. The degradation of protein was caused by fungi that could degrade proteins during fermentation into dipeptides and others into $\mathrm{NH}_{3}$ or $\mathrm{N}_{2}$ compounds that were lost through evaporation (Andarti and Wardani, 2015). The longer the fermentation was carried out, the more protein would be degraded such that the compounds which were lost due to evaporation also increased (Andarti and Wardani, 2015). 


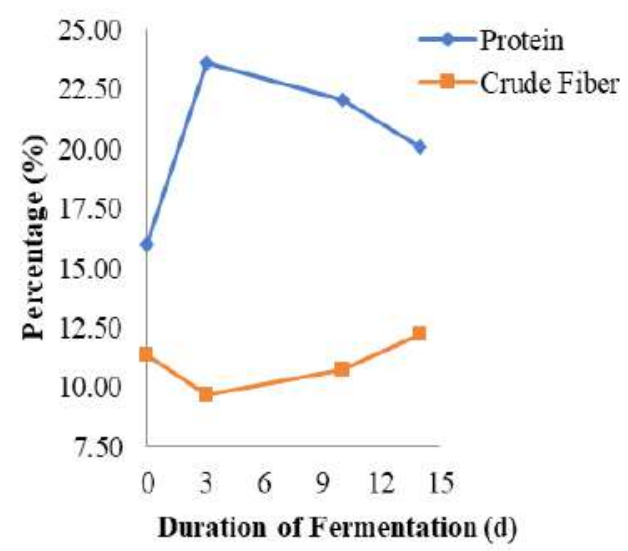

Figure 4. The effect of fermentation duration on crude protein and crude fiber levels in wheat bran

Figure 4 also indicated that fermentation also made a reduction of crude fiber. A. niger produced cellulase enzymes that could convert lignocellulose (a content of crude fiber) into glucose compounds. Glucose was a simple molecule and acted as an energy source that could be more easily absorbed by the fish. However, the longer fermentation was carried out; the more crude fiber would be concentrated on the substrate. In addition, mold growth also contributed to the existence of crude fiber through the cell wall (Ginting and Krisnan, 2006).
So, we added the buoyant materials to make the fish feed floating. Floating pellets usually help farmers to watch the feeding activity and prevent giving excessive feed (Momoh et al., 2016). We used the pith of cassava stem as the buoyant materials, with the ratio of addition to fish feed as 1:10.

Studies show that by using wheat offal in fish feed could increase the floatation of the fish feed due to its low bulk density (Momoh et al., 2016). Wheat bran contains wheat offal that would reduce the bulk density of the diets. Table 2 shows the amount of each ingredient that had to be added as completion of Eq. (5) to Eq. (10). Protein level in feed B was the same with feed C; the diffreing in the iron level. Feed $\mathrm{C}$ contained more iron than feed B.

Tilapia prefers to eat floating feed, so the feed must be made with good buoyancy. Good buoyancy in feed could be obtained by using sophisticated equipment, special manufacturing techniques, or by adding other ingredients that can cause feed floatation. Cassava stem is one of the plant's wastes which have not been utilized efficiently. Cassava stems dominate the percentage of the top of the plant, besides leaves and twigs, which is 89.1\% (Antari and Umiyasih, 2009). It shows that the existence of cassava stems as waste was quite dominant. which is composed of parenchyma cells, which has function as a storage for food reserves. Pith inside cassava's stem is a soft tissue that contains starch.

Table 4. The stability and buoyancy levels of different fish feed formulated

\begin{tabular}{ccccccc}
\hline \multirow{2}{*}{ Replicates } & \multicolumn{2}{c}{ Feed A } & \multicolumn{2}{c}{ Feed B } & \multicolumn{2}{c}{ Feed C } \\
\cline { 2 - 7 } & Stability (h) & Buoyancy (h) & Stability (h) & Buoyancy (h) & Stability (h) & Buoyancy (h) \\
\hline R1 & 20.1 & 20.00 & 29.24 & 0 & 29.24 & 0 \\
R2 & 20.4 & 20.20 & 24.39 & 5.11 & 29.20 & 8.42 \\
R3 & 23.11 & 20.00 & 24.39 & 9.50 & 24.39 & 10.28 \\
R4 & 23.11 & 20.00 & 29.24 & 20.17 & 24.00 & 20.00 \\
R5 & 23.15 & 20.10 & 29.20 & 23.07 & 28.40 & 28.20 \\
\hline
\end{tabular}

Description: Feed A was a commercial fish feed, Feed B was an artificial fish feed containing $0.085 \%$ iron, Feed C was an artificial fish feed containing $1.703 \%$ iron

\subsection{Physical test of formulated feed}

Therefore, three days was the optimal time to ferment wheat bran as one of the ingredients in fish feed. The addition of fermented wheat bran could raise the protein content in feed B as much as $5.78 \%$ and feed $\mathrm{C}$ as much as $5.17 \%$ when compared to the unfermented wheat bran. Most feed mills will only produce fish pellets for more than one ton (Pandey, 2013). For laboratory scale, it was almost impossible to produce one ton of fish feed for every variant.
There is a very wide pith inside cassava's stem Its shape that resembles a sponge makes this material have a good buoyancy, so it could be used as an additional ingredient in making fish (Rouse-Miller et al., 2013).

Table 4 illustrates that adding pith with the ratio $1: 25$ to feed $\mathrm{B}$ and feed $\mathrm{C}$ could give it a longer floating time than commercial feed. The stability of the feeds also showed satisfying results. 
Feed $\mathrm{B}$ and feed $\mathrm{C}$ were able to hold stable and were not destroyed in the water for more than $24 \mathrm{~h}$. These results exceeded SNI 01-7242-2006 standard, which states that good fish pellets must be stable in the water for at least $45 \mathrm{~min}$. Starch as much as $5 \%$ was added as an adhesive to make the feeds became more stable.

Fish feed must be sized suitably to fish's mouth. According to SNI 01-7242-2006, the standard diameter of tilapia feed for enlargement is $2-10 \mathrm{~mm}$. Table 5 consists of the results of physical testing, such as color, diameter, and length. After being mixed with pith, the feeds turned out to have a diameter of 4-6 $\mathrm{mm}$ in feed $\mathrm{B}$ and 4-7 $\mathrm{mm}$ in feed C. Feed B had light brown color while feed $\mathrm{C}$ had dark brown color. However, feed $\mathrm{B}$ and feed $\mathrm{C}$ had met the diameter requirements of tilapia in intensive aquaculture for enlargement.

\subsection{Chemical test of formulated feed}

The proximate results of the feeds is shown in Table 6. Three types of feed had met the standard quality of tilapia feed for enlargement in intensive cultivation for water content, ash content, and crude fiber. Pandey (2013) said that high ash content could make the other ingredients become indigestible, and that would affect the growth of fish.
It was illustrated in Table 6 that crude fat in feed $\mathrm{A}, \mathrm{B}$, and $\mathrm{C}$ were still below standards stated in SNI 017242-2006. On the contrary, the crude protein content in feed A, B, and C turned out fullfit the standards that is also stated in SNI 01-7242-2006.

\subsection{Fish feeding trial}

Feeds that were made in this research had high buoyancy. Floating feeds is crucial because they can raise ingestion rates, decline feed losses, and improve digestion. By using floating feeds, consumption of the fish feed. The feeding rate that we used in this research was 3\% of fish body weight per day. According to Bhujel (2013), at the weight of 100-200 g, the feeding rate of fish was $3 \%$ of body weight per day in an intensive culture system.

Table 7 shows that in the initial week, the growth rate of Nile tilapia in pond 2 had minus value. It might occur because the fish were still adapting to the new feed that had a high content of iron (Pangestika and Putra, 2019). Minus value in growth rate also found in pond 3, tilapia fed by feed C.

Table 5. The physical parameters of different fish feed formulated

\begin{tabular}{lccc}
\hline \multicolumn{1}{c}{ Parameter } & Feed A & Feed B & Feed C \\
\hline Color & Brown & Light brown & Dark brown \\
Diameter $(\mathrm{mm})$ & $3.4-3.6$ & $4.0-6.0$ & $4.0-7.0$ \\
Length $(\mathrm{mm})$ & $3.2-3.8$ & $6.0-12.0$ & $6.0-12.0$ \\
\hline
\end{tabular}

Description: Feed A was a commercial fish feed, Feed B was an artificial fish feed containing $0.085 \%$ iron, Feed C was an art ificial fish feed containing $1.703 \%$ iron

Table 6. The comparison of proximate composition among fish feeds and the standards

\begin{tabular}{|c|c|c|c|c|}
\hline Composition & Feed A & Feed B & Feed C & Standards \\
\hline Water Content ( $\%)$ & $11-13$ & 8.907 & 6.318 & $\max .12 *$ \\
\hline Ash Content (\%) & $10-13$ & 9.997 & 9.327 & $\max .15^{*}$ \\
\hline Crude Protein $(\%)$ & $26-28$ & 30.043 & 32.057 & $\max .25^{*}$ \\
\hline Crude Fiber (\%) & $4-6$ & 6.237 & 5.974 & $\max .8 *$ \\
\hline Crude Fat (\%) & $3-5$ & 2.108 & 3.509 & $\min .5^{*}$ \\
\hline Iron Level (\%) & 0.032 & 0.085 & 1.703 & $0.015-0.08 * *$ \\
\hline
\end{tabular}

Description: Feed A was a commercial fish feed, Feed B was an artificial fish feed containing 0.085\% iron, Feed C was an artificial fish feed containing $1.703 \%$ iron. * was based on SNI 01-7242-2006, ** was based on (Lall, 2000) 
Table 7. The growth rate of Nile tilapia during the feeding trial

\begin{tabular}{cccc}
\hline \multirow{2}{*}{ Week } & \multicolumn{3}{c}{$\begin{array}{c}\text { The Growth Rate of Nile Tilapia } \\
\left(\mathbf{g} \cdot \mathbf{d}^{-1}\right)\end{array}$} \\
\cline { 2 - 4 } & Feed A & Feed B & Feed C \\
\hline 0 & - & - & - \\
1 & 0.84 & -0.25 & 1.49 \\
2 & 0.77 & 0.18 & -0.09 \\
3 & 0.53 & 0.29 & 0.52 \\
4 & 0.94 & 0.26 & 1.45 \\
\hline
\end{tabular}

Pangestika and Putra (2019) reported that the reduction of fish's growth rate might be observed because of spawning; making the energy of the fish would be used for something else than for growth (Suyanto, 2010).

After feeding with feed $\mathrm{A}$ and feed $\mathrm{C}$, the growth rate of Nile tilapia decreased gradually until the third week, and raise sharply in the fourth week, while the growth rate of Nile tilapia fed by feed B was fluctuating and experienced ups and downs. Overall, the growth rate of Nile tilapia fed by feed $\mathrm{C}$ was higher than fed by feed A and feed B. Also, it was higher than the growth rate of Nile tilapia fed by rice bran as the supplementary diet (Kohinoor, et al., 1999). Nile tilapia fed by rice bran (at the average weight $94 \mathrm{~g}-125 \mathrm{~g}$ ) had a growth rate of 0.37-0.59 g/day (Kohinoor et al., 1999). The survival rates of Nile tilapia being fed by feed $\mathrm{A}, \mathrm{B}$, and $\mathrm{C}$ were $100 \%$. No mortality of fish in this research occured during the feeding trial period.

\section{Conclusions}

It was known that the addition of $0.15 \mathrm{~g} \mathrm{FeCl}_{3}$ could give the best reduction of SS in dairy wastewater. The other feed ingredients used in this research were fermented wheat bran that was obtained after 3-days fermentation. Fermentation was conducted by utilizing Aspergillus niger. Fish feed formulation was conducted by using simultaneous linear equations. Two types of fish feeds were made, feed B and feed C. Feed B contained $0.085 \%$ iron while Feed C contained $1.703 \%$ iron. Commercial feed was also used as a comparison against Feed B and Feed C. Through physical testing, it was known that Feed B and feed C had better stability and buoyancy than feed A. Good results were also obtained from the chemical test. Based on the water content, the ash content, and crude fiber, feed B and feed C still fullfiled the standards stated in SNI 01-72422006, crude protein and iron level, feed B and feed C exceeded the standard that was stated in SNI 01-72422006 for crude protein level. Feed C that was given as a supplementary diet produced a higher growth rate than feed A and feed B. Results showed that sludge of dairy wastewater and fermented wheat bran could be utilized in fish feed formulation. Feed $\mathrm{C}$ that was given as a supplementary diet produced a higher growth rate than feed A and feed B. Results showed that sludge of dairy wastewater and fermented wheat bran could be utilized in fish feed formulation.

\section{Acknowledgements}

The authors sincerely thank all staff of Wastewater Treatment Plant (WWTP) of PT Sari Husada Unit II Kemudo-Klaten. This study could be conducted because they had given the opportunity to do research collaboration.

\section{Authors' Contributions}

WP did the main research, made the draft of the manuscript, and did some revision on the draft. SP made the concept and supervised WP in the research. All authors have fully contributed to the research and the final manuscript.

\section{Conflict of Interest}

The authors declare that they have no competing interests

\section{Funding Information}

This research was self-funded.

\section{References}

Afrianto, E., \& Liviawaty, E. (2005). Fish feed and its development. Yogyakarta: Kanisius Publisher. pp. 20-25.

Andarti, I. Y., \& Wardani, A. K. (2015). Effect of fermentation time on chemical, microbiological, and organoleptic characteristics of miso black soybean (Glycine $\max (L)$ ). Jurnal Pangan dan 
Agroindustri, 3:889-898

Antari, R., \& Umiyasih, U. (2009). Optimum utilization of cassava plants and the waste as ruminant animal feed. Wartazoa, 19(4):191-199.

Arru, B., Furesi, R., Gasco, L., Madau, F. A., \& Pulina, P. (2019). The introduction of insect meal into fish diet: The first economic analysis on european sea bass farming. Sustainability, 11: 1697. DOI: 10.3390/su11061697.

Bhosale, S. V., Bhilave, M. P., \& Nadaf, S. B. (2010). Formulation of fish feed using ingredients from plant sources. Research Journal of Agricultural Sciences 1(3): 284-287.

Bhujel, R. C. (2013). On-farm feed management practices for Nile tilapia (Oreochromis niloticus) in Thailand. In M.R. Hasan and M.B. New, eds. On-farm feeding and feed management in aquaculture. (pp. 159-189).Rome: FAO Fisheries and Aquaculture Technical Paper No. 583.

Coloso, R. M. (2015). Feed formulation for sustainable aquaculture. In: M. R. R. Romana-Eguia, F. D. Parado-Estepa, N. D. Salayo, \& M. J. H. LebataRamos (Eds.), Resource Enhancement and Sustainable Aquaculture Practices in Southeast Asia: Challenges in Responsible Production of Aquatic Species. (pp. 223-230). Proceedings of the International Workshop on Resource Enhancement and Sustainable Aquaculture Practices in Southeast Asia 2014 (RESA). Tigbauan, Iloilo, Philippines: Aquaculture Department, Southeast Asian Fisheries Development Center.

Essington, M. E. (2004). Soil and water chemistry: an integrative approach. Florida: CRC Press. pp. 4350 .

Felix, E., \& Oscar, E. V. (2018). Floating and stability effect on fish feed pellets using different concentration of baobab leaf meal (Adansonia digitata). Asian Journal of Fisheries and Aquatic Research 1(4): 1-6. DOI: 10.9734/ AJFAR/2018/43555.

Indariyanti, N., \& Rakhmawati. (2013). Improvement of nutrition quality of cocoa and lamtoro leaf skin waste through fermentation as tilapia feed protein base. Jurnal Penelitian Pertanian Terapan, 13(2):108-115.

Indonesian National Standards (SNI). (1992). Food and Beverage Testing Methods: SNI 01-2891-1992. Jakarta: National Standardization Agency.

Indonesian National Standards (SNI). 2006. The Artificial Feed for Tilapia (Oreochremis niloticus) in Intensive Cultivation: SNI 01-7242-2006. Jakarta: National Standardization Agency.
Ginting, S. P., \& Krisnan, R. (2006). The effect of fermentation using several Trichoderma strains and different incubation periods on the chemical composition of palm kernel cake. The paper has been presented on Seminar Nasional Teknologi Peternakan dan Veteriner. pp. 939-944.

Hassan, E. G., Alkareem, A. M. A., \& Mustafa, A. M. I. (2008). Effect of fermentation and particle size of wheat bran on the antinutritional factors and bread quality. Pakistan Journal of Nutrition 7(4): 521-526. DOI: 10.3923/pjn.2008.521.526.

Kohinoor, A. H. M., Modak, P. C., \& Hussain, M. G. (1999). Growth and production performance of red tilapia and Nile tilapia (Oreochremis niloticus Lin.) under low-input culture system. Bangladesh Journal of Fisheries Research 3(1): 11-17.

Koohestanian, A., Hosseini, M., \& Abbasian, Z. (2008). The separation method for removing of colloidal particles from raw water. American-Eurasian Journal of Agricultural \& Environmental Science, 4(2): 266-273.

Lall, S. P. (2000). Nutrition and health of fish. In: Cruz -Suárez, L.E., Ricque-Marie, D., Tapia-Salazar, M., Olvera-Novoa, M.A. y Civera-Cerecedo, R. (eds.). Avances en Nutrición Acuícola V. Memorias del V. Paper presented at the Simposium Internacional de Nutrición Acuícola. pp. 13-22.

Mirwandhono, E., Bachari, I., \& Situmorang, D. (2006). Nutritional value test of cassava skin fermented with Aspergillus niger. Jurnal Agribisnis Peternakan, 2(3): 91-95.

Momoh, A. T., Abubakar, M. Y., \& Ipinjolu, J. K. (2016). Effect of ingredients substitution on binding, water stability and floatation of farm-made fish feed. International Journal of Fisheries and Aquatic Studies 4(3): 92-97.

Nazullawaty, R. (2013). Utilization of Sludge of Dairy Wastewater with Fermentation of Aspergillus niger to Increase Growth and Protein Content of Tilapia, Oreochromis niloticus. Surakarta: Faculty of Mathematics and Science, Universitas Sebelas Maret. pp 26-40.

Pandey, G. (2013). Feed formulation and feeding technology for fishes. International Research Journal of Pharmacy 4(3): 23-28. DOI: 10.7897/2230-8407.04306.

Pangestika, W., \& Putra, S. (2019). The utilization of sludge of dairy wastewater as an additive to increase protein and iron levels in fish. $A A C L$ Bioflux 12(5): 1832-1840.

Rand, G. M. (2003). Fundamentals of aquatic toxicology: Effects, environmental fate and risk ( $2^{\text {nd }} \mathrm{Ed}$.). (pp. 
479-480). USA: Taylor \& Francis Group.

Rouse-Miller, J., Bowrin, V., Sirju-Charran, G., \& Sutton, F. (2013). Inverse oriented stem cutting generate tuberous stems in cassava manihot esculenta crantz: An alternative sink site. Journal Plant Biochemistry and Physiology, 1(4):1-3. DOI: 10.4172/2329-9029.1000117.

Sarparastzadeh, H., Saeedi, M., Naeimpoor, F., \& Aminzadeh, B. (2007). Pretreatment of municipal wastewater by enhanced chemical coagulation. International Journal of Environmental Research 1 (2): 104-113.

Supriatna. (2005). Increasing nutritional quality of passion fruit skin through fermentation process with Aspergillus niger as Animal Feed Material. Prosiding Temu Teknis Nasional Tenaga Fungsional Pertanian. pp. 117-121.

Suyanto, S. R. (2010). Tilapia hatchery and enlargement Jakarta: Swadaya Publisher.

Uliza, C., Dewiyanti, I., Hasri, I., \& Muchlisin, Z. A. (2017). Growth performance, survival rate and feed utilization of Peres fish (Osteochilus vittatus) at several concentration of vitamin $\mathrm{C}$ L-ascorbyl-2- phosphate-magnesium (L-ApMg). Jurnal Ilmiah Mahasiswa Kelautan dan Perikanan Unsyiah, 2(2): 229-239.

Weiner, E. R. (2000). Applications of Environmental Chemistry: A Practical Guide for Environmental Professionals. Florida: CRC Press LLC. pp. 55-60.

Wulan, P. P. D. K., Dianursanti, G. M., \& Nugroho, W.A. (2010). Optimization of coagulant use in coal wastewater treatment. Prosiding Seminar Nasional Teknik Kimia 'Kejuangan'. pp. 1-6.

Yang, H., Li, X., Huan, D., Xu, Z., Zhang, Y., \& Leng, X. (2018). Effect of three positively buoyant dietary supplements on the buoyancy of feces, growth and intestinal health of Tilapia, Oreochremis niloticusx, O. aureus. Aquaculture and Fisheries 3(2): 72-78. DOI: 10.1016/j.aaf.2018.01.004.

Yusak, Y. (2004). Effect of temperature and ph of the acetate buffer on cmc hydrolysis by cellulase enzyme from Aspergillus niger extract in mixed media of cassava and bran. Jurnal Sains Kimia, 8(2):35-37. 